\title{
Dehydration effects on seedling development of four range species
}

\author{
M. BASSIRI, A.M. WILSON, AND B. GRAMI
}

\begin{abstract}
The effects of temporary drought periods of semiarid regions were simulated by dehydration of germinating seeds of crested wheatgrass (Agropyron desertorum), Rusian wildrye (Elymus junceus), alfalin (Medicago sativa), and cicer milkvetch (Astragalus cicer) in 8 constant humidity environments, ranging from -10 to -220 MPa for 4 days. Combined effects of root excision and temporary dehydration at -22 to $-160 \mathrm{MPa}$ were also studied. Subsequent growth of seedlings was evaluated in growth performance tests under favorable soil moisture conditions. When the initial roots were killed by dehydration, survival of grasses depended on the development of seminal lateral root(s) from the scutellar nodes, and survival of legumes depended on development of a new meristem at the distal end or along the side of hypocotylroot axis. The effect of dehydration was more drastic on the legumes than on the grasses, particularly at more severe conditions. While temporary dehydration of -59 MPa had little effect on grasses, it reduced the percent emertence of the legumes by about $70 \%$. In the $-220 \mathrm{MPa}$ treatment, emergence percentages of crested wheatgrass, Russian wildrye, alfalfa, and cicer milkvetch were 59, 35,6 , and 1 , respectively, and percentages of rooted seedlings were $58,12,3$, and 1, respectively. Under combined effects of excision and dehydration at $-160 \mathrm{MPa}$, emergence percentages of the 4 species were $50,34,14$, and 0 , respectively, and their root lengths decreased by $37,42,44$, and $100 \%$, respectively. Within species variation in tolerance of dehydration suggested opportunities to select and breed for this characteristic.
\end{abstract}

Key Words: crested wheatgrass, Russian wildrye, alfalifa, cicer millkvetch, drought tolerance, plant selection

In arid and semiarid zones with low and unreliable rainfall, germinating seeds are often exposed to periods of drought, the severity and duration of which may vary. Germinating seeds of various plant species may respond differently to dry conditions. Levitt (1972) and Brown (1977) used the term "drought tolerance" as equivalent to "dehydration tolerance." The latter was defined by Kramer (1978) as the ability of plant protoplasm to survive drought without irreversible injury.

Crested wheatgrass (Agropyron desertorum) is a perennial bunchgrass which is widely used for rangeland rehabilitation on

Authors are assistant professor, Department of Plant Science, Isfahan University of Technology, lsfahan, Iran; plant physiologist (deceased), USDA-ARS, Crop Resesearch Lab., Colorado State University, Fort Collins 80253; and postdoctoral researcher, Department of Agronomy and Range Science, University of California, Davis 95616.

Research was supported by Forage and Range Management Research, USDAARS. Authors wish to thank Dr. John Menke for review the manuscript and making helpful suggestions.

Manuscript accepted 2 May 1988. light-textured soils of both shrublands and grasslands where the rainfall is between 230 to $380 \mathrm{~mm}$ (Hafenrichter et al. 1949). Wilson (1971) indicated that seeds of this species were able to resume their physiological processes after being exposed to wet and dry periods. On the other hand, Russian wildrye (Elymus junceus) is a perennial bunchgrass which grows slowly in the seedling stage and is somewhat more susceptible to moisture stress during emergence and establishment (Bleak and Keller 1974).

Townsend et al. (1975) found that alfalfa (Medicago sativa) was the most promising legume species under dryland conditions and also the legume which could compete favorably with crested wheatgrass by the fourth year after establishment. In contrast, cicer milkvetch (Astragalus cicer) has poor seedling vigor and relatively slow germination and establishment, although it may tolerate moderate drought conditions (Townsend and McGinnies 1972).

Because these grasses and legumes are often seeded in mixtures on semiarid lands, it is important to understand their comparative drought tolerance during germination and establishment.

The objective of this study was to evaluate and quantify the effects of various degrees of temporary dehydration during the germination stage on the emergence and development of 4 promising species of grasses and legumes for seeding in dry regions. The combined effects of temporary dehydration and root excision on the subsequent growth of seminal lateral roots in grasses and of replacement tap roots in legumes were also examined.

\section{Materials and Methods}

Experimental materials included 'Nordan' crested wheatgrass, 'Vinall' Russian wildrye, 'Ladak'alfalfa, and 'Lutana' cicer milkvetch.

\section{Dehydration Experiment}

Light weight seeds and inert material were removed in a seed blower. They were then treated with bis (dimethylthiocarbamoyl) disulfide. Legume seeds were scarified. This experiment included 3 sequential steps:

(1) Seed germination: Seeds were germinated at $20^{\circ} \mathrm{C}$ under favorable moisture conditions until the seminal root had extended to a length of 3 to $5 \mathrm{~mm}$.

(2) Dehydration treatment: Germinating seeds were exposed to a dehydration treatment by placing them in constant humidity trays for 4 days. Saturated salt solutions of sodium sulfate, potassium chloride, sodium chloride, magnesium acetate, calcium nitrate, potassium carbonate, calcium chloride, and potassium acetate had maintained constant humidities equivalent to water potentials of $-10,-22,-37,-59,-92,-120,-160$, and -220 mega- 
pascals (MPa), respectively, at $25^{\circ} \mathrm{C}$ prior to insertion of germinating seeds. Seeds did not touch the salt solutions, but lost water vapor to the constant humidity air. Hassanyar and Wilson (1978) found that the water content of germinating seeds of crested wheatgrass and Russian wildrye reached equilibrium within 2 days under humidity.

(3) Growth performance test: To evaluate the effects of temporary dehydration treatments, 25 control or treated seeds were planted at a depth of $1 \mathrm{~cm}$ in plastic pots $(15 \mathrm{~cm}$ diameter by $15 \mathrm{~cm}$ depth) filled with autoclaved sandy loam soil. Soil was maintained at approximately $-0.03 \mathrm{MPa}$ by surface irrigation with distilled water. Emergence and growth performance during the 10-day test were evaluated under both growth chamber and greenhouse conditions. Growth chambers were maintained at $20^{\circ} \mathrm{C}, 70 \%$ relative humidity, a 12-hour daylength, and photosynthetically active radiation of $400 \mu \mathrm{E} \mathrm{m}^{-2} \mathrm{sec}^{-1}$. Greenhouse conditions were maintained at $20^{\circ} \mathrm{C}$ to $25^{\circ} \mathrm{C}$, a variable relative humidity, 12-hour daylength (supplemented with sodium vapor lamps), and maximum midday photosynthetically active radiation of $300 \mu \mathrm{E} \mathrm{m}^{-2} \mathrm{sec}^{-1}$.

At the end of the 10-day growth test, number of emerged seedlings per pot was recorded. It was found that not all seedlings that emerged had developed roots, nor did all seedlings with roots emerge. Therefore, the percentage of seedlings that developed at least one root during the growth test was determined. Roots were washed with a fine spray of water over a $1-\mathrm{mm}$ screen. The length of the shoot and depth of the longest root were measured from the planting level. Shoots and roots from each pot were separated, oven-dried ( $70^{\circ} \mathrm{C}$ for 24 hours) and weighed. Shoot and root data were averaged over the number of seedlings emerged and number of rooted seedlings, respectively. Biomass change was calculated as root plus shoot weight minus seed weight at the end of the 10-day test.

\section{Excision-Dehydration Experiment}

The distal 2-mm portion of the root of legumes and the entire seminal primary root of grasses were excised before the germinating seeds were exposed to the 4-day dehydration treatments at -22 , -92 , and $-160 \mathrm{MPa}$. Two additional treatments were included in which germinating seeds were not exposed to temporary dehydration: (1) roots were excised, and (2) roots were left intact.

Pots $(20 \mathrm{~cm}$ diameter by $20 \mathrm{~cm}$ depth) were filled with autoclaved sandy loam soil and water was added to increase soil moisture content to $15 \%$ (approximately field capacity). Fifty germinated seeds were planted in each pot and covered first with about $2 \mathrm{~mm}$ of moist soil, then with a layer of $2 \mathrm{~cm}$ of air-dried soil to reduce soil surface evaporation rate. At the end of the 20-day growth test, percentage emergence, shoot and root length, and shoot and root weight were determined in the same manner as indicated earlier.

Randomized complete block designs were employed in both experiments and significant differences among means were determined by Tukey's test (Steel and Torrie 1980). A polynomial regression was used to determine the effect of water potential on root development.

\section{Results and Discussion}

\section{Dehydration Experiment}

Temporary dehydration treatments significantly $(P=0.01)$ reduced the emergence of seedlings of the 4 species during the 10-day test under favorable soil moisture conditions (Table 1). The effect of dehydration was more drastic on the legumes than on the grasses, particularly at more severe conditions. While temporary dehydration of $-59 \mathrm{MPa}$ had little effect on grasses, it reduced the percent emergence of the legumes by about $70 \%$. Very similar trends were obtained for the emergence percentages in the growth chamber and greenhouse tests. In a similar study with green needlegrass (Stipa viridula Trip.), Fulbright et al. (1984) demonstrated that percent emergence was zero at $-22 \mathrm{MPa}$.

Trends in root development for all species were similar to those for percent emergence in response to dehydration treatments, although under higher stress conditions root development was somewhat more adversely affected than was percent emergence (Table 1). In both the growth chamber and the greenhouse tests, species were significantly different $(P=0.01)$ in their ability to develop roots after they had been exposed to dehydration treatments. In grasses, presence of seminal lateral root primordia, and in legumes, ability of root tissues to produce meristematic tissue in the hypocotyl-root axis are important factors in drought tolerance and survival of the seedlings (Hassanyar and Wilson 1978). Temporary dehydration of $-37 \mathrm{MPa}$ had no effect on subsequent root development in the grass species in growth chamber test, whereas it reduced percent rooted seedlings by about $75 \%$ in both legume species. In a similar study (Fulbright et al. 1984), when the seminal primary root of germinating seeds of needlegrass (Stipa viridula Trin) was excised or injured by dehydration (-10 MPa), seedlings developed up to 3 (average of 1.3) seminal lateral roots per seedling. They observed that no additional seminal roots developed when seminal primary root was undamaged. In the present study, root development was consistently more affected in cicer milkvetch than in alfalfa under similar stress conditions. The response of both grass species to dehydration treatments, in terms of percentage of seedlings with a root, was found to be linear, in contrast to a quadratic response in both legume species.

The water potentials during temporary dehydration which resulted in subsequent development of at least 1 root in $50 \%$ of the seedlings were calculated from the regression equations for the growth chamber test. The water potentials for crested wheatgrass, Russian wildrye, alfalfa, and cicer milkvetch were $-247,-129,-32$, and $-22 \mathrm{MPa}$, respectively. For crested wheatgrass, the value was obtained by extrapolation of the regression equation because the lowest value for percent of seedlings with at least 1 root was $58 \%$. Bleak and Keller (1974) also observed that germinating seeds of crested wheatgrass were more tolerant to dehydration than those of Russian wildrye.

Germinating seeds of legumes exposed to dehydration treatments below -59 MPa did not develop roots in most replications during the 10-day test. An analysis of variance for both grasses and legumes was, therefore, performed only on the root depth and root weight data of the first 5 treatments (control, $-10,-22,-37$, and -59 $\mathrm{MPa}$ ). Differences in root depth as well as in root weight per seedling caused by species, treatments, and the species $\times$ treatment interaction were significant $(P=0.01)$ in both growth chamber and greenhouse tests. Root depth of the 4 species were nearly the same in the control treatment (Table 1 ). The dehydration treatments, however, inhibited the extension of roots in legumes more than in grasses. While a water potential of $-37 \mathrm{MPa}$ reduced the root depth of grasses by $32 \%$, the reduction for the legumes was $74 \%$ under similar conditions. The results clearly indicated that root extension of cicer milkvetch was more adversely affected than that of alfalfa.

Since the grasses did develop roots in almost all treatments and replications, 2 additional analyses of variance, including all treatments, were conducted on the root depth and root weight per seedling of the $\mathbf{2}$ grass species. Differences in root depth and in root weight caused by species, treatments, and the species $X$ treatment interaction were significant $(P=.01)$ in both analyses. It appeared that dehydration treatments inhibited root extension in Russian wildrye more than it did in crested wheatgrass.

Root weights per seedling of crested wheatgrass, Russian wildrye, alfalfa, and cicer milkvetch in the $-59 \mathrm{MPa}$ dehydration treatment, expressed as the percentage of control treatment, were: 41.9 , $36.6,28.5$, and 42.1 , for the growth chamber test, respectively. Corresponding data for shoot weights per seedling were 46.1, 45.8, 36.2 , and 66.1, respectively. Both average root weight and shoot weight per seedling of cicer milkvetch were elevated by the high weights of very few superior seedlings that survived the dehydration treatment.

In water potentials below -59 $\mathrm{MPa}$, seedling survival of the 
Table 1. Effects of temporary dehydration treatments (MPa) during seed germination on subsequent emergence, and root and shoot development of 4 species in frowth chamber and greenhouse tests under favorable soll moisture conditions.

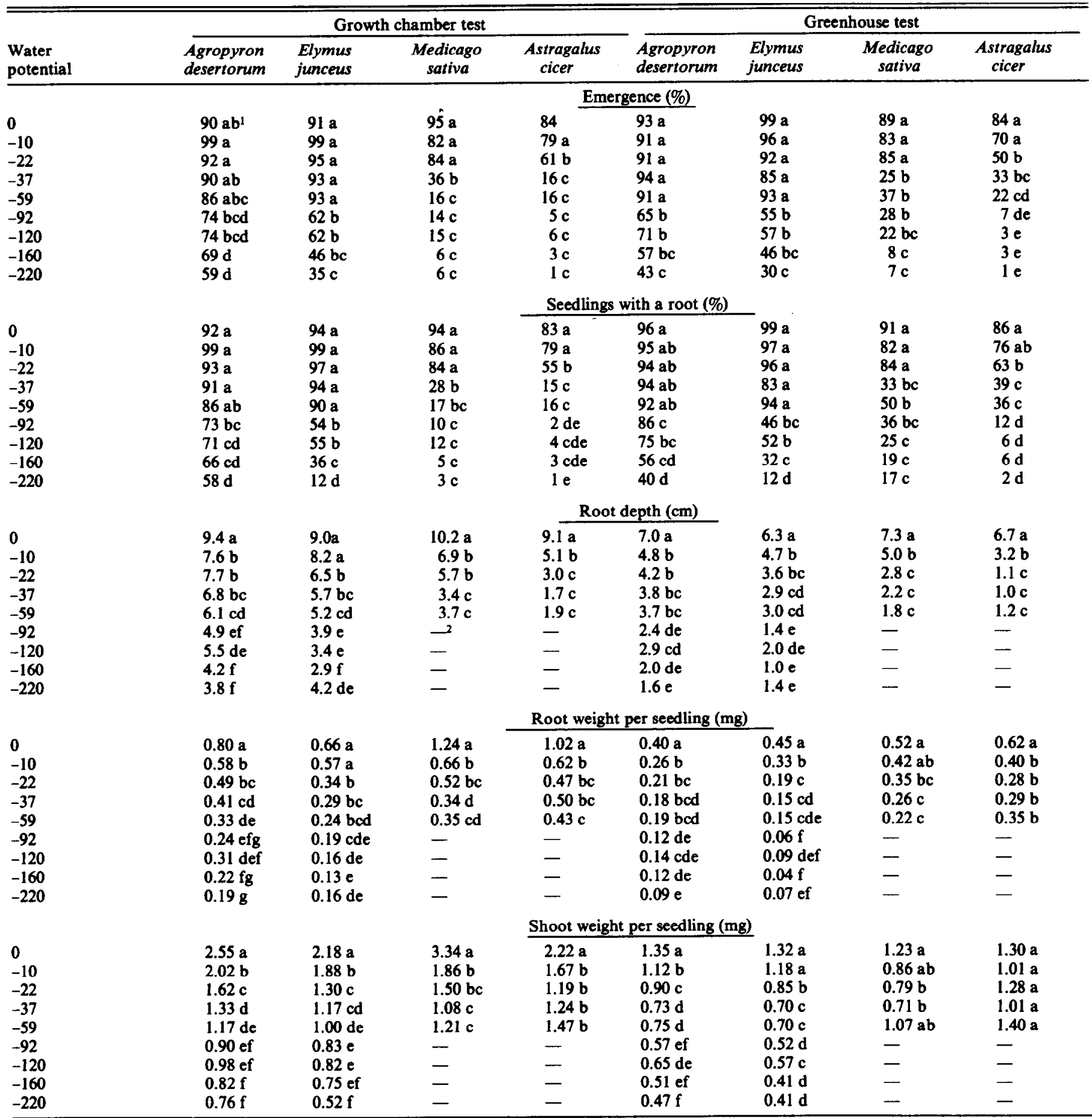

'Each value is the mean of eight replications. Differences caused by species, treatments, and species $\times$ treatment interactions were significant in all cases in both the growth chamber and the greenhouse tests. Means within each column followed by a similar letter are not significantly different $(P=0.05)$.

2Because of the very low percentage survival of legumes in the last 4 treatments, root depth, and root and shoot weights per seedling were not calculated in these treatments.

legumes was too low to consider their root and shoot weights as representative of the species. Faster emergence and more vigorous growth resulted in more gain in biomass in alfalfa and crested wheatgrass during the 10-day growth performance test than in the other 2 species examined. Dehydration treatments caused a delay in emergence, and probably reduced the growth rate. This may be the explanation for lower gain or more loss of biomass in seedlings that were temporarily dehydrated during early germination stages than in the control seedlings.
Grass species developed 1 or 2 seminal lateral roots per seedling when the roots were excised or the dehydration treatments damaged or killed their seminal primary roots. Legume species developed replacement tap roots whenever their root apices were damaged, killed, or excised. Replacement tap roots in legume species were either formed as branches or as a continuation of the original tap root, with a distinct reduction in diameter. Alfalfa and cicer milkvetch had similar patterns of root development, although cicer 
Table 2. Effects of root excision and temporary dehydration treatments (MPa) during seed germination on subsequent emergence, and root and shoot growth of 4 species in pots at the end of a 20-day growth performance test in the greenhouse with seedlings limited to the initial soil water supply.

\begin{tabular}{|c|c|c|c|c|c|}
\hline \multicolumn{2}{|c|}{ Treatment } & \multicolumn{4}{|c|}{ Species } \\
\hline Excision 1 & $\begin{array}{l}\text { Dehyd- } \\
\text { ration }\end{array}$ & $\begin{array}{l}\text { Agropyron } \\
\text { desertorum }\end{array}$ & $\begin{array}{l}\text { Elymus } \\
\text { junceus }\end{array}$ & $\begin{array}{l}\text { Medicago } \\
\text { sativa }\end{array}$ & $\begin{array}{l}\text { Astragalus } \\
\text { cicer }\end{array}$ \\
\hline
\end{tabular}

\begin{tabular}{llllll}
\hline \multicolumn{5}{l}{ Percent emergence (\%) } \\
\cline { 3 - 5 }+ & 0 & $84 \mathrm{a}^{2}$ & $90 \mathrm{a}$ & $93 \mathrm{a}$ & $86 \mathrm{a}$ \\
+ & 0 & $85 \mathrm{a}$ & $88 \mathrm{a}$ & $90 \mathrm{a}$ & $70 \mathrm{a}$ \\
+ & -22 & $84 \mathrm{a}$ & $82 \mathrm{a}$ & $53 \mathrm{~b}$ & $18 \mathrm{~b}$ \\
+ & -92 & $64 \mathrm{ab}$ & $69 \mathrm{ab}$ & $20 \mathrm{c}$ & $8 \mathrm{~b}$ \\
+ & -160 & $50 \mathrm{~b}$ & $34 \mathrm{~b}$ & $14 \mathrm{c}$ & $0 \mathrm{~b}$
\end{tabular}

\begin{tabular}{|c|c|c|c|c|c|}
\hline & & \multicolumn{2}{|c|}{ Root weight (mg) } & & \\
\hline $\begin{array}{l}- \\
+ \\
+ \\
+ \\
+\end{array}$ & $\begin{array}{l}0 \\
0 \\
-22 \\
-92 \\
-160\end{array}$ & $\begin{array}{l}3.6 \mathrm{a}^{2} \\
2.6 \mathrm{ab} \\
2.3 \mathrm{bc} \\
1.5 \mathrm{~cd} \\
1.0 \mathrm{~d}\end{array}$ & $\begin{array}{l}3.0 \mathrm{a} \\
2.0 \mathrm{~b} \\
1.5 \mathrm{bc} \\
1.1 \mathrm{bc} \\
0.7 \mathrm{c}\end{array}$ & $\begin{array}{l}3.3 \mathrm{a} \\
2.0 \mathrm{~b} \\
1.2 \mathrm{bc} \\
1.1 \mathrm{bc} \\
0.9 \mathrm{c}\end{array}$ & $\begin{array}{l}2.3 \mathrm{a} \\
1.4 \mathrm{ab} \\
0.6 \mathrm{bc} \\
0.8 \mathrm{bc} \\
0.0 \mathrm{c}\end{array}$ \\
\hline \multicolumn{6}{|c|}{ Shoot weight (mg) } \\
\hline $\begin{array}{l}- \\
+ \\
+ \\
+ \\
+\end{array}$ & $\begin{array}{l}0 \\
0 \\
-22 \\
-92 \\
-160\end{array}$ & $\begin{array}{c}10.7 \mathrm{a} \\
8.9 \mathrm{ab} \\
7.7 \mathrm{~b} \\
5.4 \mathrm{c} \\
4.0 \mathrm{c}\end{array}$ & $\begin{array}{l}7.6 \mathrm{a} \\
6.2 \mathrm{ab} \\
4.9 \mathrm{bc} \\
3.8 \mathrm{c} \\
3.3 \mathrm{c}\end{array}$ & $\begin{array}{r}11.2 \mathrm{a} \\
7.6 \mathrm{~b} \\
4.8 \mathrm{c} \\
4.6 \mathrm{c} \\
3.2 \mathrm{c}\end{array}$ & $\begin{array}{l}6.7 \mathrm{a} \\
4.1 \mathrm{~b} \\
2.1 \mathrm{bc} \\
2.3 \mathrm{bc} \\
0.0 \mathrm{c}\end{array}$ \\
\hline \multicolumn{6}{|c|}{ Root length (mm) } \\
\hline $\begin{array}{l}- \\
+ \\
+ \\
+ \\
+\end{array}$ & $\begin{array}{l}0 \\
0 \\
-22 \\
-92 \\
-160\end{array}$ & $\begin{array}{l}18 \mathrm{a} \\
17 \mathrm{ab} \\
16 \mathrm{ab} \\
13 \mathrm{bc} \\
11 \mathrm{c}\end{array}$ & $\begin{array}{r}17 a \\
16 a \\
14 a \\
13 a \\
9 b\end{array}$ & $\begin{array}{l}16 \mathrm{a} \\
14 \mathrm{ab} \\
12 \mathrm{abc} \\
10 \mathrm{bc} \\
9 \mathrm{c}\end{array}$ & $\begin{array}{l}14 \mathrm{a} \\
12 \mathrm{ab} \\
7 \mathrm{c} \\
9 \mathrm{bc} \\
0 \mathrm{~d}\end{array}$ \\
\hline \multicolumn{6}{|c|}{ Shoot length (mm) } \\
\hline $\begin{array}{l}- \\
+ \\
+ \\
+ \\
+\end{array}$ & $\begin{array}{l}0 \\
0 \\
-22 \\
-92 \\
-160\end{array}$ & $\begin{array}{l}22 \mathrm{a} \\
21 \mathrm{a} \\
20 \mathrm{ab} \\
18 \mathrm{bc} \\
16 \mathrm{c}\end{array}$ & $\begin{array}{l}18 \mathrm{a} \\
18 \mathrm{a} \\
16 \mathrm{ab} \\
15 \mathrm{~b} \\
13 \mathrm{~b}\end{array}$ & $\begin{array}{c}11 \mathrm{a} \\
9 \mathrm{ab} \\
7 \mathrm{bc} \\
7 \mathrm{bc} \\
6 \mathrm{c}\end{array}$ & $\begin{array}{l}7 \mathrm{a} \\
6 \mathrm{ab} \\
4 \mathrm{~b} \\
4 \mathrm{~b} \\
0 \mathrm{c}\end{array}$ \\
\hline
\end{tabular}

IIn the excision treatments $(+)$, the entire seminal primary root in grasses and $2 \mathrm{~mm}$ of the root tip of legumes were removed from germinating seeds before transferring to the pots.

${ }^{2}$ Each vaue is the mean of 4 replications. Means within each column followed by a similar letter are not significantly different $(P=0.05)$.

milkvetch roots generally formed more branches than did alfalfa roots.

\section{Excision-Dehydration Experiment}

Differences in various characteristics of seedling growth caused by species, treatments, and species $X$ treatment interactions were all significant $(P=0.01$ ) except that the species did not respond differently to treatments in relation to shoot length. Emergence percentages of crested wheatgrass, Russian wildrye, alfalfa, and cicer milkvetch, after an excision and temporary dehydration treatment at $-16 \mathrm{MPa}$ were $50,34,14$, and 0 , respectively (Table 2). Emergence of crested wheatgrass and Russian wildrye decreased linearly with a decrease in water potential in dehydration treatments. In alfalfa and cicer milkvetch, the decrease in emergence seemed to be curvilinear, indicating high tolerance to dehydration in a few seedlings.

The survival advantages of seminal lateral roots in crested wheatgrass and Russian wildrye, as well as replacement tap roots in alfalfa and cicer milkvetch, were confirmed in the dehydrationexcision experiment, where seedlings were limited to the initial soil water supply (about $-0.03 \mathrm{MPa}$ ) in the pots. The roots which developed after excision and dehydration treatment at $-160 \mathrm{MPa}$ were shorter and probably less effective than the seminal primary roots of grasses and original tap roots of legumes. The results of excision-dehydration experiment indicate that the effects of dehydration were more important than the effects of excision in impairment of root growth and development. Root lengths and root weights of all 4 species were affected more by the combination of excision and dehydration treatments than by only the excision treatment.

Shoot and root length of all 4 species as well as shoot and root dry weight of the grasses decreased linearly with decreasing water potentials in temporary dehydration treatments (Table 2). Shoot and root dry weight of the legume species, however, appeared to have decreased in a curvilinear manner with decreasing water potentials in temporary dehydration treatments.

The excision treatment simulated the theoretical situation in which the only effect of dehydration might be the killing of the entire seminal primary root in grasses and the root apex in legumes. The excision treatment alone did not cause significant reductions in shoot or root lengths of either grasses or legumes, nor did it reduce root or shoot weights of grasses, but caused moderate reduction in root and shoot weights of legumes. The combination of excision and dehydration treatment, however, caused moderate to severe reductions in growth parameters of grasses and legumes. This combination at $-160 \mathrm{MPa}$, decreased root lengths of crested wheatgrass, Russian wildrye, alfalfa, and cicer milkvetch by 39,42 , $44,100 \%$, respectively (Table 2). One could rank the 4 species investigated for most to least drought tolerant during germination stages as follows: crested wheatgrass, Russian wildrye, alfalfa, and cicer milkvetch.

Frequency distribution for rooting depths of the 4 species indicated great within-species variation among seedlings as affected by each dehydration treatment. Even in the more severe dehydration treatments, there were a number of seedlings in each species that had adequate rates of root elongation. In semiarid zones, such plants should be able to extend their roots into moist layers of the soil profile ahead of the drying soil front. Frequency distributions can be used to determine which dehydration treatments are suitable for screening in a selection program for a given species under given environmental conditions.

\section{Literature Cited}

Bleak, A.T., and W. Keller. 1974. Emergence and yield of 6 range grasses planted on 4 dates using natural and treated soils. J. Range Manage. 27:225-227.

Brown, R.W. 1977. Water relations of range plants, p. 97-140. In: R.E. Sosebee (ed.) Rangeland plant physiology. Soc. Range Manage. Denver, Colo.

Fulbright, T.E., A.M. Wilson, and E.F. Redente. 1984. Effects of temporary dehydration on growth of green needlegrass (Stipa viridula Trin) seedlings. J. Range Manage. 37:462-464.

Hafenrichter, A.L., L.A. Mullen, and R.L. Brown. 1949. Grasses and legumes for soil conservation in the Pacific Northwest. USDA Misc. Pub. 678.

Hanson, C.H., and D.K. Barnes. 1973. Alfalfa, p. 136-147. In: M.E. Heath, et al. (eds.) Forages, lowa State Univ. Press, Ames.

Hassanyar, A.S., and A.M. Wilson. 1978. Drought tolerance of seminal lateral root apices in crested wheatgrass and Russian wildrye. J. Range Manage. 31:254-258.

Kramer, P.J. Drought tolerance, stress, and the origin of adaptations. U.S.-Australian workshop on adaptation of plants to water and high temperature stress. Carnegie Institution of Washington, Palo Alto, Calif. Nov. 6-10, 1978.

Levitt, J. 1972. Responses of plants to environmental stress. Academic Press, New York.

Steel, R.G.D., and J.H. Torrie. 1980. Principles and procedures of statistics. 2nd edit. McGraw-Hill Book Co., Inc., New York.

Townsend, C.E., and W.J. MeGinnies. 1972. Establishment of 9 forage legumes in the Central Great Plains. Agron. J. 64:699-702.

Townsend, C.E., G.O. Hinze, W.D. Ackerman, and E.E. Remmenga. 1975. Evaluation of forage legumes for rangelands in the Central Great Plains. Colorado State Univ. Exp. Sta. Gen. Ser. 942. Fort Collins, Colo.

Wilson, A.M. 1971. Anylase synthesis and stability in crested wheatgrass seeds at low water potentials. Plant Physiol. 48:541-546. 